\title{
WhichAmerica? \\ Brazilian intellectual formulations about Latin America at the turn of the century and their impacts on the constructions of national identity
}

\author{
Qual América? \\ Formulações intelectuais sobre a América Latina na virada do século XX e seus impactos na \\ construção da identidade nacional brasileira \\ ¿Cuál América? \\ Formulaciones intelectuales brasileñas sobre la América Latina a finales del siglo XIX/ \\ comienzos del siglo XXy sus impactos en la construcción de la identidad nacional brasileña
}

Rafael Rossotto Ioris*

\section{Abstract}

At the turn of the $20^{\text {th }}$ century, with the coming of a new political regime in the country, Brazilians intellectuals actively engaged in a creative reflection about the historical relation of their nation with its surrounding Spanish-speaking neighbors. And although no unified view was to emerge, as a whole these works and ensuing debates offered an opportunity for these publicly engaged writers to reinsert, under a new yet still largely critical light, the regional context into much needed discussions on national identity and associated national projects. How this new dynamic operated and how they are situated within the long-term of Brazilian history are the focus of this study.

Keywords: Intellectuals. Latin America. National identity.

Doutor em História Latino-Americana pela Emory University, EUA. Professor Assistente do Departamento de História da Universidade de Denver, EUA. E-mail: rafael.ioris@du.edu

Recebido em 01/04/2016 - Aprovado em 01/09/2016 http://dx.doi.org/10.5335/hdtv.16n.2.6928 


\section{Intercontinental dynamics: from common colonial origins to distinctive statehood}

Though not always in good terms, Portuguese and Spanish America shared much in common from their respective inceptions. To be sure, the two parallel Iberian colonial projects in the New World were closely related, at times even interconnected. Further complicating things, from its slower start, the occupation of the Brazilian territory gradually evolved, mainly by means of the so-called Bandeiras and Entradas, into areas of Spanish America. The unification of the Spanish and Portuguese crowns, from 1580 to 1640 , played an additional catalytic role in the process of having settlers from both empires intermix in the American continent. Similarly, the fact that the Spanish crown did not take organized preventive actions to repudiate the increasing number of Portuguese incursions farther west, into the originally defined Spanish territory, played a major role in the expansion of the Portuguese in South America (GOES, 1991).

Starting to pave a somewhat different course, as national independence movements began around the first quarter of the nineteenth century and former Spanish colonies broke apart into many new republics, a significant part of the Brazilian political elites - the majority of whom were involved in the process of making Brazil into an independent and unified kingdom felt that the high levels of uncertainty and violence taking place in Spanish America had to be managed in ways that would not affect the territorial integrity of their new, Portuguese-speaking empire. In fact, compared to the many wars of independence in Spanish America, the process involved in the Brazilian independence movement was based on the notion of continuity. The ruling dynasty had been transferred to a different region of the kingdom in 1808, as a side-effect of the Napoleonic expansionist drive in Europe, and in 1822 the heir to the Portuguese throne, Pedro, ruling prince of Brazil, proclaimed himself as the emperor of the newly independent kingdom of Brazil. Over time this event would increasingly be articulated by the Brazilian elites to assert the uniqueness of the Brazilian case, particularly when contrasted to the newly established, Spanish-speaking republics (MAGNOLI, 1997).

Along these lines, the new Brazilian monarchy would posit a national sense of identity largely by claiming a Brazilian dynastic tradition assumed capable of inserting the new nation within the context of the traditional European ruling dynasties. European societies were increasingly seen as the model to be followed and thus, conversely, the general perception of many monarchical Brazilian politicians was that Spanish-American Republics were unstable, prone to be ruled by strong local political bosses and to suppress individual, liberal rights. These political tendencies of its neighbors were seen as hostile to the Brazilian tradition of peace and stability and monarchical elites insisted in a selfportrait that pictured them as belonging to a traditional European dynasty and culture. To civilize the country progressively meant 
the creation of a national culture through the use of a state apparatus, a process that implied that the vast national territory would have to remain intact, given that former Spanish-American domains were breaking apart into several new states.

The process of constructing a national identity for the new state involved metaphoric usage of the images that the monarchy promoted of its neighbors. Indeed, the fragmentation and political disruptions taking place in Spanish America would prove the existence of a strong, national, and superior identity in the former Portuguese lands of South America. Along these lines, Brazil's monarchical regime, European dynastic background, stable institutions, vast territory, natural richness, and vast population were to become central elements articulated to define the country's national character in the following decades.

Interestingly enough, this sense of uniqueness proposed by the Brazilian monarchy seems to have been shared by the Spanish American Republics, which tended to exclude Brazil from their projects of political unification or integration (BETHELL, 2010). Moreover, the War of the Triple Alliance (1864-1868), which is seen by some as a key moment when the Brazilian monarchy acted as sub-imperial power, helped reinforce Brazil's self-proclaimed exclusive position within the region, thus deepening a preexistent sense of difference posited by Brazil in relation to its Latin-American neighbors. Nonetheless, if during the empire much of the Brazilian foreign policy was articulated in contrast to its surrounding region, with the advent of the Republican period in the latter years of the nineteenth century Brazil started to reassess its national character, and therefore, its relationship with its Spanish-speaking neighbors, as will be examined in detail below.

\section{The context of the late Nineteenth Century in Brazil:seeking for a new beginning}

With the establishment of the Republican regime in Brazil in 1889, it became paramount for the new ruling groups to provide references that could help in the formulation of political institutions and an ideological structure for the nation. Three main political projects and ideologies quickly found themselves in competition, as proposed by Carvalho (1990):

a) American Liberalism: This project argued for a contractual view of society that defined individuals as formally equal despite their different material conditions to maneuver within a competitive, marketbased social context. It was mostly sponsored by the coffee-growing elites of the state of Sao Paulo, whose political interests did not include a broader level of social inclusion, but rather aimed at creating a liberal structure of power;

b) French Jacobinism: It was a project that tended to favor political actions harkening back to models of the public square democracy and enlightened despotism, as well as models of transformation from above, 
to be performed by a strong ruler. Its main supporters were the urban middle classes, mostly in the city of Rio de Janeiro - self-employed, educated, propertied urbanites - all of whom supported ideas of direct, classic democracy;

c) Positivism: A project that involved a pseudo-scientific, elitist view of society, which was, nonetheless, supposedly aimed at socio-political transformation that would provide more social inclusion and institutional modernization. This project was mostly popular among the new generation of military leaders that since the 1880s had become very influential in the military academies.

It should be noted that each of these models presented not only alternative views about the state institutions, but also about the broader organization of society. In fact, Jacobins, for one, claimed a return to a classic model of democracy, with direct participation as the goal. Liberalism assumed that direct democracy was neither applicable nor advisable in the modern age. Its supporters hoped to create political institutions that would represent the wishes of those individuals who, in a free-market society, had proven to be the most suitable to govern. Positivism was probably the most utopian project of the three. It sought to recreate a golden age where individuals were elements of a higher harmony expressed by all of humanity, organized around a new civic religion, and having the family as its most basic unit.
Clearly the implementation of a republic in Brazil involved a great deal of political, ideological, and philosophical debate. Many European ideas were discussed, supposedly absorbed, and, at times, implemented in a very piecemeal fashion. Yet, despite its democratic discourse, the liberal state structure that was legally created in 1891 and, in reality, implemented in 1894, did not involve larger segments of the population in its political and economic programs (CARVALHO, 1987). In fact, although this brand of imported classic Liberalism defended formal democratic principles, there were clear limits to their actual implementation in the county. The liberal faith in the possibilities that the market would provide for the population never came to fruition, and the Brazilian Liberalism of early twentieth century helped to consolidate a political regime in which a formal democracy was constructed on the fragile basis of a population that was mostly illiterate, with an electoral system that was only accessible to about two per cent of the people. Moreover, Liberalism was cleverly used to consolidate the power of the southern landed aristocracy, while the initial attraction that Positivism exerted among some social groups was not capable of providing an alternate political platform. Some social groups, such as the socialists, anarchists, and the syndicalist movement devised marginal proposals, but none was able to offer an effective political project for social and institutional needs and realities of the time.

After first five turbulent years, a Liberal Republic was consolidated in Brazil. The natural reaction from most of the subaltern population, in terms of attempting 
to influence the political process and obtain public services, was creating parallel forms of accessing the structures of power in a minimalist type of state. Most Brazilians participated in politics not through institutional channels, such as parties and interest groups, but rather through a network of personal contacts within the state bureaucracy. This became conducive to a situation defined by Carvalho (1987, p. 78) as "estadania (stateship) instead of cidadania (citizenship)." These structural limitations to more progressive means of political representation notwithstanding, among local elite circles, however, a rich intellectual discussion was underway at this very moment. It was mainly concerned with a perceived need that the country should go through a cultural overhaul, a process that should provide a fresh-start aimed at culturally matching the level of innovations brought about by the new political regime.

As a result, at the turn of the nineteenth century, a national self-examination got under way in Brazil (JOANILHO; DENIPOTI, 1997). Members of the elites increasingly saw that the generalized sense that the nation had to be re-founded as an opportunity to articulated new models and projects for the country. The Romantic generation of mid-1800s had given rise to the idea of the indigenous as the embodiment of the nation. This notion would be quickly questioned with the economic and political transformations that took place around the 1870s, when the southern states of Brazil consolidated their preeminence in the economy, and Republicanism (following the War of the Triple Alliance) became a key element of the political debate. Rational thought, literary Realism, scientific evolution, and pragmatic political agendas, increasingly became the categories upon which the political debate would be built (IORIS, 2013). Thus, progressively, the metaphysical romanticism of the empire was, thus, replaced by the scientific realism of the Republic. Yet, the simple act of accepting 'scientific' formulations in vogue during late 1880s in Europe on the part of Brazilian intellectual and political elites would have led to a very pessimistic portrayal of the Brazilian reality.

In effect, the evolutionary hierarchical character that imbued most of these pseudoscientific theories of the time placed Brazil of early twentieth century on the lower end of the civilizational scale, given the country's mostly mixed-race and illiterate population. In this sense, to prevent such a self-deprecating image to be reproduced in the country, Brazilian intellectuals of early twentieth century, many of whom exerted political functions as well, absorbed the scientific models of the time in a largely piecemeal and hybrid fashion (SCHWARCZ, 1993). This selective process of ideological absorption would indeed 'pick and choose' elements from those theories seen as convenient to socio-political projects defined around a supposed, self-acclaimed need that a self-titled 'enlightened' white elite would control the processes of modernizing the country and integrating the lower races into the national context. Within this rubric, defined by the rising importance given to the new scientific discourse, the "man of science" played a major role for he held the 
keys to the future. Members of the intellectual elite also attempted to advocate the notion that Brazil was in the process of resolving its racial question through inter-racial births that would produce a whiter nation - as argued by the 'scientific theories of the time, which were increasingly popular among Brazilian elites (SKIDMORE, 1974).

Another aspect of how nationalism was conceived by members of the Brazilian intellectual elites of this period related to their assessment that the country lacked a national literature with features that could be considered essentially Brazilian. This problem had to be resolved in order for the country to succeed as a real modern nation. Some authors who focused on examining the need to formulate a Brazilian literature and culture promoted the need for massive social integration through efforts in public education. Manoel Bomfim and Alberto Torres (to be studied below) rejected the doctrines of inherent differences among races, arguing that Brazil's escape from its relative backwardness could be achieved through a serious examination into the real socio-historical reasons for the country's lack of development.

Intellectual elites, thus, occupied themselves increasingly with issues related to the national identity of the country at the dawn of the twentieth century. They tried obsessively to define the specific characteristic that would give the country its main features as part of a larger project of shaping the nation's future (LUCA, 1998). The country was increasingly seen as an incomplete project, a nation in formation, in transition to something more stable, a nation under construction. And the country's history, geography, language, literature, politics, and ethnicities all became subjects of study for the self-proclaimed intellectual guides who were supposed to offer paths to be followed and measures to be taken. This elite saw itself as the only group capable of pointing the way to the nation: They alone would be able to formulate projects that would reflect the country's true vocation, express its true values, and, was implicitly assumed, guarantee a successful path of development.

To be sure, much of the debate that was taking place in Brazil at the time was also manifested in many countries of SpanishAmerica (BAGGIO, 1998). Beyond the regime change that to a large extent led to a renewed debate in Brazil about the country's identity, other dynamics, also present in SpanishAmerican nations, influenced the tone of the discussions. Among the most important socio-economic and political developments were the pace of industrialization, the process of urbanization, a new cycle of European immigration, the enlargement of both middle and proletarian classes, and new cultural dynamics resulting from innovative artistic and intellectuals ideas as well as technological transformations in the means of communication and transportation. These dynamics inspired new ideological and political discussions concerning the ways in which these same transformations could and should be ordered and progress promoted. Throughout the entire Latin-American continent, the turn of the nineteenth century was a time of intense political and intellectual debate, where communalities related to the 
process of modernization were manifested. Some of the key formulations produced in the Brazilian context and which are nonetheless representative of broader historical developments, are examined below.

\section{Brazilian intellectual conceptions of Latin America at the dawn of the Twentieth Century}

Because of the need to find new ideological references for Republican nationalism, Brazilian intellectuals, who were usually also involved in broadly defined policy-making, began to pay attention to the national experiences Spanish-American nations. ${ }^{1}$ This section reviews relevant works of five key Brazilian intellectuals between 1889 and 1930, the period in which a new political and intellectual credo was crafted. The authors here examined (Eduardo Prado, Silvio Romero, Manoel de Oliveira Lima, Manoel Bomfim, and Alberto Torres) were chosen because they creatively and painstakingly reflected upon the questions of how Brazil should relate to the new nations of Spanish America and how their construction of a national identity should be perceived within the Brazilian context.

\section{Eduardo Prado and the American Illusion}

Son of one of the most aristocratic families of the country, Eduardo Prado (1860-1901) was a monarchist who reflected on the destiny of the country at the end of the nineteenth century. His tone was pessimistic and was usually very critical of what he saw as the political future of the nation. In what is considered to be his major work, $A$ ilusão americana (American illusion), Prado (1961) critically characterized the United States as a hypocritical nation that exerted a harmful influence in the continent with its rhetoric of Americanism. He, thus, opposed the PanAmerican project that argued for some level of political integration among American nations by assuming a list of commonalities among them, such as European cultural roots and a Republican structure of government.

The first edition of Prado's book (published in 1893) was harshly censored by the fledgling Republic, which in turn attracted attention to one of the author's main critiques, namely the impulse expressed by the creators of the new regime to implement U.S. political ideas and models in Brazil. Prado argued that instead of attempting to mimic political structures, each nation in the continent should create its own political regime according to its own cultural, linguistic, racial, religious, and historical traditions. In Prado's own words, "The American fraternity is an illusion, and the best example is the case of the Iberian (Spanish) nations of America, where there is more enmity, wars, violence, and conquest than among European nations of different backgrounds and political regimes" (1961, p. 18). Brazil, vis-à-vis Europe and separated from Iberian America by language and traditions, was said to share a moral or a political system with its neighbors, according to Prado. Moreover, the experience of new Spanish-speaking American nations represented a tragicomic succession of 
dictatorships, personal usurpations of power, and financial debacles.

Prado also argued against the idea of a natural Latin-American natural affinity, as well as against the notion of an American sphere of influence. Indeed, he went to great lengths to portray the Monroe Doctrine as a fallacy, utilized to defend specific U.S. interests in the region. He continued his criticism of uncritically copied foreign models by arguing that Spanish-American nations, by copying U.S. notions, denied their own traditions, thus producing disaster for themselves (1961, p. 39). Conversely, he conceived Brazil as having achieved its independence by respecting its monarchical traditions. Republicanism was, thus, described as a threat to the organic characteristics of the Portuguesespeaking nation. Republican rule was also said to be prone to several social evils such as political and moral corruption. For him, the United Sates did not represent a mode to be followed despite its economic wealth and development for it failed to offer a moral stand worthy of replication. Indeed, he believed the U.S. to be "a society that does not respect human life" (1961, p. 173).

The search for a moral model was particularly important as Prado saw LatinAmerican societies in a desperate need of values because their mestizo reality had produced, on his view, low moral and cultural standards. Hence, he argued that Brazil should continue on a path of selfsufficiency, maintaining strong international relations with European nations instead of attempting to insert itself within an unstable and authoritarian regional political context.
In the end, even though Prado's analysis subsumes Latin America into the broader context of the continent, its still seems relevant to examine how this important Brazilian author of the late nineteenth century characterized the type of interaction that Brazil should undertake with Latin America. Defined essentially in opposition to Brazil, Latin (Spanish) America is seen as an inherently distinct and potentially dangerous reality - notions that would be replicated by other authors, and that, at times, still find some support among contemporary Brazilian intellectuals.

\section{Silvio Romero and the need for a Brazilian philosophical thought}

An influential writer from the Northeast region of the country, and a member of what was called the Recife School, Silvio Romero (1851-1914) published various works during the last decades of the nineteenth century, mostly dealing with literary criticism. Nevertheless, Romero's writings defined him as a socio-political commentator, someone who structured much of the intellectual debate at his time, and whose influence in shaping the intellectual scenario of the turn of century in Brazil was probably unparalleled. In the work entitled Philosophy in Brazil, Romero argued that philosophical writing was part of the process of building a modern national identity that would insert Brazil into the reality of civilized societies. Reviewing what he considered to be relevant philosophical works published in Brazil, Romero examined books from various 
fields, including natural history, and social and literary criticism. He would then argue that, although those books were relevant, the country still lacked a consistent body of intellectual production.

Examining many of the ideas of Tobias Barreto, who had been his professor in Recife, Romero claimed that his mentor's promotion of Positivism during the 1860s should be considered an important development, as this philosophy offered a promising classificatory system for a nation that still lacked a systematic self-examination. For him, Positivism was a very useful system of thought, which provided a tool to be applied to the ideas and political propositions of a politically dynamic period. Furthermore, Positivism justified and explained the nation's evils by pointing to the areas where scientific progress was not present, and also by placing the country within a hierarchical system of development for human societies. Brazil's very position within this system was said to offer some sense of hope given the correct measures were taken, the nation, Romero assumed, could evolve and eventually become a developed, modern, civilized nation (ROMERO, 1878).

Romero's famous caustic style is expressed in this book, particularly when he reviews the legalist culture of his country. He claims that the Brazilian cultural context is deeply defined by a lack of scientific development, where legal reforms are attributed with deontic powers to correct social problems; and, thus, urges more philosophical reflection and selfexamination to avoid implementing foreign models and ideas that were not suitable to
Brazil's own reality. Romero's views on Latin America, it should be said, are mostly expressed in a tangential manner, usually to emphasize his point about the need for the country to become civilized through the strengthening of a national culture.

In his views, the entire Latin-American continent suffered from similar problems. However, as a whole, the solutions he espoused did not imply more political, cultural, or even social involvement within the Latin-American context. Instead, he vocally argued for the creation of a strong national culture adhering to the traditional characteristics of the Brazilian nation. In one sentence, for Romero, as for many others at the time, Spanish America was relevant only as an analytical reference that helped in the articulation of a nationalist project.

\section{Oliveira Lima and the conservative criticism of Latin Americanism}

Historian and influential diplomat Manoel de Oliveira Lima (1867-1928) was another important intellectual of the same period. In 1911, he published a series of lectures presented at the Sorbonne intended to demonstrate that, since its inception and throughout its entire history, Brazil was a product of European culture (OLIVEIRA LIMA, 1997). Oliveira Lima was a devoted monarchist, who credited the Brazilian monarchy with providing a long period of stability, peace, and domestic freedom. He compared Brazil's past to that of the Spanishspeaking Latin-American states, when he could claim that these countries were highly prone to follow populist projects promoted 
by authoritarian leaders, which usually had led to social unrest and violent undertakings.

One of his major contributions to the historiography of Brazil is his strong defense of the uniqueness of the historical evolution, and therefore, the character of the country. In his views, despite being closely tied to Europe, Brazil always had to deal with its unique multiracial characteristic. Oliveira Lima argued that Brazil's process of independence was initiated with the repressive trend that a new Portuguese ruling elite, in 1821, tried to reduce the status achieved by Brazil in the previous 13 years. Therefore, he believed, it would be very unfortunate that the monarchical regime implemented in Brazil after 1822 had been seen throughout the nineteenth century as retrograde, and necessarily less democratic, when compared to the Latin-American republicanism of the time. For him, accurate comparisons with Spanish America at the time of the Brazilian empire would clearly show that more political freedom was enjoyed under the monarchy than in almost every Spanish-speaking American state. In his own words, "[i]mperial Brazil represented a model of liberty and peace for Latin America and furnished at least a real image of civilization, reflected from the throne, at the time when Spanish American Societies struggled in disorder and savagery" (OLIVEIRA LIMA, 1966, p. 91).

Moreover, in his view, the monarchy

[...] realized in Brazil its function as protector of the rights of the uncultivated [...] masses, who entrusted themselves to it in order not to be despoiled and tortured by intriguing and pitiless oligarchies which were shortsighted and actuated by the most selfish motives" (1966, p. 117).
The unity of the country would also be seen as a triumph as contrasted with the fiasco of the attempted organization of a great Spanish-American confederation. Federalist ideals, as proposed by some LatinAmerican politicians, were directly related to the misfortunes of Spanish America. Also according to the author, these ideals would have produced a naïve aspiration to liberty without a sense of legitimacy, tradition, and order. And the end result was that of anarchy, political strife, and social unrest. Finally, like other influential Brazilian writers of the turn of the century, Lima believed Latin America represented a dangerous political reality, when not disorder and chaos. He counseled, therefore, Brazil to follow its own path of evolution. And, thus, once again, a close level of interaction with the broader region was not seen as an advisable course of action for the country.

\section{Manoel Bomfim and the Latin American project as an alternative}

Manoel Bomfim (1868-1932), whose first book was published in Paris in 1903, was another intellectual who reflected on the topic of Latin America. He was an author who in many regards was ahead of his time, particularly in rejecting the racist theories en vogue at the time in Europe and Brazil. Bomfim saw Latin American problems as not deriving from intrinsic, natural character of the peoples of the region, but rather from the model of colonization implemented there by Iberian peoples and its lasting impact in the region. The author also published many textbooks and pedagogical works, having 
become the director of public education of the city of Rio de Janeiro during the first decade of the twentieth century. The focus of Bomfim's criticism is the local elites, which he claimed maintained a colonial mentality even after the national independence had taken place.

In the work entitled America Latina: males de origem (Latin America: original ills), Bomfim states that the general sense in Europe concerning Latin America, at the turn of the century, was that it was a rich, exuberant region, but politically unstable, dominated by violent political bosses, prone to coups, and with an ignorant and dishonest population (BOMFIM, 1993). He conversely urged for an entire overhaul on the real reasons for the existence of such a reality, and probed into the matter of why many Latin Americans accepted these very characterizations, thus, assuming an inherently pessimistic idea about their own possibilities for development. In the same piece, he tried to uncover the reasons for Latin-American underdevelopment with an examination that was still in many ways constructed within the evolutionist language of the time, even though he clearly attempted to reject biologically or ethnically based justifications for the various levels of development among different nations. Indeed, his usage of a biological model of explanation was restricted to the notion of parasitism. This model stated that a body that has had its resources sucked out by a parasite suffers to the point of finding itself in a state of misery. However, the causes for such state of misery could be found in the intrinsic character of the organism being exploited. Therefore, once the parasite has been expelled from the body, the latter can grow and blossom on the basis of its intrinsic potentialities (1993, p. 54).

Interestingly, Bomfim speaks of Latin America as a whole, seeing the region as unified by the experience of parasitism, a result of similar colonial experiences. His arguments are largely of a historical nature, namely that the reasons for the current problems can be found in the historical patterns of underdevelopment experienced throughout Latin America. For him, underdevelopment was inherent in Iberian cultures, which had always underestimated the value of work, relying instead on slave labor for its economic production. Another deplorable trait of these civilizations was the role attributed to the state as the guarantor of a regime of exploitation of subjugated populations. And, in these lines, once again, the patrimonial nature of the state structure, the proliferation of unproductive positions, and the lack of interest of promoting real basis for economic development were seen as Iberian evils that could be eliminated. Indeed, Bomfim described what he called an untapped potential for Latin America, a region that, given that the right measures were taken, could become as successful as developed nations (1993, p. 307).

In a later work, published in 1930, Bomfim revised some of his earlier positions, even though much of the argument is congruent with the main line of ideas presented earlier. In this book, entitled O Brasil nação (Brasil as nation), Bomfim continues to argue that Brazil had been depleted of its richness by a colonial elite, and subsequently by a new, domestic elite. Thus, 
the very process of Brazilian independence from Portugal could be said to be proof of the continuation of colonial mentality in the nation And, in a general sense, he saw Brazil as a repressed nation that, similarly to the rest of the Latin-American region, still had not experienced real democratic institutions (BOMFIM, 1996). Thus, while he cared little for regional elites, Bomfim was essentially positive about the populations of these countries. Later in life, he argued that the solution for the region's social problems was to be found in nationalistic political projects, such as the Mexican Revolution. Still, in many regards, he was clearly an author that saw more similarities among the nations of Latin America than most of his contemporaries. It is interesting to note that the acceptance of Bomfim's ideas among Brazilian intellectual circles of early twentieth century was very marginal.

Alberto Torres and the New Nationalist Emphasis

Alberto Torres (1865-1917) was of major social thinker of the early twentieth century in Brazil. A native of rural Rio de Janeiro state, Torres was a highly respected writer, former judge of the Supreme Court, Minister of Justice, national deputy and governor of the state of Rio de Janeiro. A key proponent of nationalism, Torres was never a radical, whose popularity grew during the 1920s and 1930s among intellectual groups of various political orientations. His main criticism related to the lack of a clear ideological direction for the country among the political and intellectual elites, as well as their tendency to implement foreign ideas as a panacea for every national problem.

Given his strong conviction that each nation has peculiarities that require corresponding unique measures, in one of his major works ( $O$ problema nacional brasileiro, The Brazilian national problem, of 1914), Torres tried to provide answers to Brazil's problems based on its own reality. He vehemently opposed one of the main legal and political cornerstones of the 1889 Republican regime: A Federalist structure of government. As a strong nationalist, Torres was also disappointed with the fact that the 1891 Brazilian Constitution had been closely based on the American Federal Constitution. Alternatively, he proposed a centralized executive branch that would be more responsive to the society, particularly given electoral reforms and a modernization of the state bureaucracy would be implemented (TORRES, 1978).

As part of his argument, Torres compared Brazil with the United States, claiming that historical differences could best explain the differing results between the stages of development of the two nations. Brazil was plagued since colonial times by a mentality of disbelief in its own people and in its potentialities as a nation. Describing U.S. interests in the American continent, he claimed that the northern neighbor dragged the entire region onto an implicit liberal alliance that was not beneficial to the development of the region as a whole. Torres also denounced the notion that there was a natural alliance of interests in the hemisphere and that an American unity was a desirable goal (TORRES, 1978, p. 256). 
Still according to this influential social commentator and legal scholar, Brazil's problems derived not from its racial intermixing, nor from its heritage of Portuguese people and culture. Instead, the reason for the country's underdevelopment was to be found on its lack of a national project. Brazil was a nation without a sense of patriotism and a nationalist project of development. Similar to Romero, Torres' focus is on the case of Brazil and only tangentially deals with the reality of the rest of Latin America. His treatment of the region is purely instrumental, in order to suggest that the region faced similar problems to the ones faced by Brazil. These problems, once again, were seen as of a national nature, which required a nationalist approach in their resolution.

\section{The evolution of nationalist formulations and the consolidation of a new political path in Brazil}

Alberto Torres' influence on the intellectual context of early 1920s and 30s in Brazil is extremely significant. Many authors would see in him and in his rejection of foreign solutions to the country's problems, as well as his strong defense of a strategic understanding of the country's reality, key inspirations to their own works Torres indeed represented a center of gravitation for most of the authors who considered themselves to be part of a new generation that would reform the state in order to create a modern Brazilian identity for the country. Many of these authors acknowledged the need to examine the national reality in more systematic, possibly scientific manner, expressing, at the same time, an increasing skepticism about the cosmopolitanism and Pan-Americanism of members of the BelleÉpoque generation.

In this sense, the intellectual generation that followed the turn of the century emphasized even more the notion that Brazil suffered from a lack of contact and understanding of its own national reality, as well as from its tradition of copying foreign models to resolve its own problems. It is important to notice, though, that both of these problems were seen as curable, given that a enlightened national elite could understand the national reality and lead the country into a new phase of prosperity. Here again, the elite saw the need to create a new national intelligentsia in order to provide a deeper and clearer understanding of the national evils and therefore of their solutions. Increasingly the first years of the twentieth century were seen as representative of how liberal ideologies were insufficient in offering answers to the county's problems. A renewed interest was placed on matters of collective values, national identities, and national solidarity, all of which were closer to a corporatist (many times defined as organic by the authors) model of state and society.

Interestingly, most of the new intellectual formulations proposed during the 1920s and 30s argued for a privileged role for the intellectuals in the management of the state and organization of the society in general. And although no consensual definition of what nation meant was clearly formulated, Liberalism was clearly rejected. 
Liberal ideas were seen either as inherently flawed, or not at all applicable to the Brazilian reality. A new, organic state, led by a strong, scientifically enlightened executive, and aware of the national needs, became the main political models and aspirations around which the debates of the early 1930s would take place. Many projects discussed in the intellectual debates of the second quarter of the twentieth century involved the application of the state apparatus (by taking hold of it, reforming it, and above all changing it) in order to implement new projects that would resolve many of the nation's problems (PECAUT, 1989).

These intellectuals indeed tended to identify themselves as reformers, who would use centralized state power in order to attend to nation's needs. Most of them held a hierarchical view of society. They saw themselves as conducting the nation from above. Ironically, this sort of perception and these political projects linked the modern intellectuals of the twentieth century with the intellectual elite that served the monarchy of the nineteenth century. Both sought to create a state bureaucracy that was said to have been the main reason of why Brazil did not face the upheavals that other Latin-American nations confronted after their independence.

\section{Concluding remarks}

This article critically reviews review the ideas of five relevant Brazilian writers at the turn of the nineteenth century concerning their notions about Latin America. More specifically, it examines how these ideas impacted the construction of a modern Brazilian national identity. Given that in Brazil the intellectual tradition has always been closely concerned with political issues, it was not surprising to see that every one of the authors investigated articulated his own project for the nation at a time of institutional change. That all of these projects would touch upon the notion of Latin America was not surprising given the intellectual and political tradition of portraying the region in specific, historically defined, terms that were useful to construct a national Brazilian identity, either in opposition or in tandem with its surrounding region.

The five authors examined are certainly representative of their time, but do not exhaust the debate in which their writings were engaged. In fact, others relevant authors of the time include Joaquim Nabuco, Euclides da Cunha, and Jose Verissimo, whose contributions expanded beyond the scope of this analysis. Nonetheless, I am convinced this study captures the essence of how the ideas of Brazilian thinkers of the time exerted a long-term impact in the construction of a new sense of national identity during the first decades of the twentieth century. The emphasis in the majority of these works was inserting a negative connotation to the idea of a natural, politically advisable affinity among Latin-American nations. Latin America was mostly seen through representations of anarchy, social unrest, fragmentation, authoritarianism, demagoguery, when not savagery and chaos.

Whether or not History is more than the study of change over time, including also the 
study of continuities, it seems only natural that similar images and ideas utilized since colonial times to argue for the uniqueness or exceptionalism of the Brazilian case would reappear in the context of the expedited modernization of the turn of the century. The notions proposed by the intellectuals of the Brazilian Belle Époque would, in the end, reinforce an identity for the nation that relied on and argued for a nationalist (when not even self-sufficient) path of development. The long-term influence of these notions can, at the moment, only be suggested and further research is certainly needed.

Moreover, based on what has been examined here, it is not surprising to see that Brazil would repeatedly over the course of the twentieth century promote institutional political and economic structures that did not heavily depend on the country's integration within the larger context of Latin America. In fact, even is more recently some degree of integration has been sought, it is still true that the sense of belonging to the region is still an open, unresolved issue in the discussions about Brazilian national identity.

\section{Resumo}

Na virada do século XX, com o advento de um novo regime politico, intelectuais brasileiros engajaram-se ativamente em uma rica reflexão sobre o relacionamento com seus vizinhos de língua espanhola. Embora nenhuma visão hegemônica tenha se consolidado, em geral, os textos tratando do assunto, e os debates politicos e sociais a eles associados, possibilitaram a esses escritores e pensadores orgânicos a oportunidade de reinserir, ainda que maneira crítica, o contexto regional dentro das discussões tratando da temática de identidade nacional. Como essas dinâmicas históricas operavam e como elas se situam no curso mais amplo da história brasileira são os temas centrais desse artigo.

Palavras-chave: Intelectuais. América Latina. Identidade nacional.

\section{Resumen}

A finales del siglo $X X$, con la llegada de un nuevo régimen político en el país, los intelectuales brasileños participaron activamente en una reflexión creativa acerca de la relación histórica de su nación con los vecinos de habla hispana a su alrededor. Y aunque no haya surgido una visión unificada, en conjunto estas obras y debates subsiguientes ofrecieron una oportunidad para que estos escritores comprometidos públicamente reinsertaran, bajo una nueva visión crítica, el contexto regional en discusiones muy necesarias sobre la identidad nacional y proyectos nacionales relacionados. Cómo se ha operado esta nueva dinámica y, por fin, cómo la misma se sitúa dentro de la larga duración de la historia de Brasil son el foco de atención de este estudio.

Palabras clave: Intelectuales. Latinoamérica. Identidad Nacional. 


\section{Endnotes}

1 During this same period much attention was paid to the case of the United States and perhaps the case of this nation was the most influential one - as the very republican constitution will be modeled after the U.S. constitution. However, as much as possible the U.S. influence will not be central to this study as its focus resides on the experience of Latin-American countries.

\section{Bibliography}

BAGGIO, Katia G. A 'outra' América: a América Latina na visão dos intelectuais brasileiros das primeiras décadas republicanas. 1998. Doctoral Dissertation presented to the Department of History at the University of São Paulo, São Paulo, 1998.

BETHELL, Leslie. Brazil and Latin America. Journal of Latin American Studies, Cambridge, v. 42, n. 3, p. 457-485, 2010.

BOMFIM, Manoel. A América Latina: males de origem. Rio de Janeiro: Topbooks, 1993.

. O Brasil nação: realidade da soberania brasileira. Rio de Janeiro: Topbooks, 1996.

CARVALHO, José M. A formação das almas: o imaginário da República no Brasil. São Paulo: Companhia das Letras, 1990.

Os bestializados: o Rio de Janeiro e a República que não foi. São Paulo: Companhia das Letras, 1987.

GOES, Synésio S. Navegantes, bandeirantes, diplomatas: aspectos da descoberta do continente, da penetraçãodoterritóriobrasileiro extra-Tordesilhas e do estabelecimento das fronteiras da Amazônia. Brasília: IPRIS, 1991.

IORIS, Rafael R. Ici comme là-bas: European Thought and the Ideational Construction of National Identity in Nineteenth-Century Brazil. Revista de História de América, Cidade do México, v. 148, n. 1, p. 9-28, 2013.
JOANILHO, A.; DENIPOTI, C. O jogo das possibilidades: ensaios em história da cultura. Curitiba: Aos Quatro Ventos, 1997.

OLIVEIRA LIMA, Manoel de. Formação histórica da nacionalidade brasileira. Rio de Janeiro: Topbooks, 1997.

The evolution of Brazil compared with that of Spanish and Anglo-Saxon America. New York: Russell \& Russell, 1966.

LUCA, Tânia R. A revista do Brasil: um diagnóstico para a (N)ação. São Paulo: Unesp, 1998.

MAGNOLI, Demétrio. O corpo da pátria: imaginação geográfica e política externa no Brasil (1808-1912). São Paulo: Unesp, 1997.

PECAUT, Daniel. Os intelectuais e a política no Brasil: entre o povo e a nação. São Paulo: Ática, 1989.

PRADO, Eduardo. A ilusão americana. São Paulo: Brasiliense, 1961.

ROMERO, Sílvio. A filosofia no Brasil: ensaio crítico. Porto Alegre: Deustche Zeitung, 1878.

SCHWARCZ, Lilia M. O espetáculo das raças: cientistas, instituições e questão racial no Brasil, 1870-1930. São Paulo: Companhia das Letras, 1993.

SKIDMORE, Thomas E. Black into white: race and nationality in Brazilian thought._Oxford: Oxford University, 1974.

TORRES, Alberto. O problema nacional brasileiro: introdução a um programa de organização nacional. Brasília: Editora Gráfica Nacional, 1978. 